
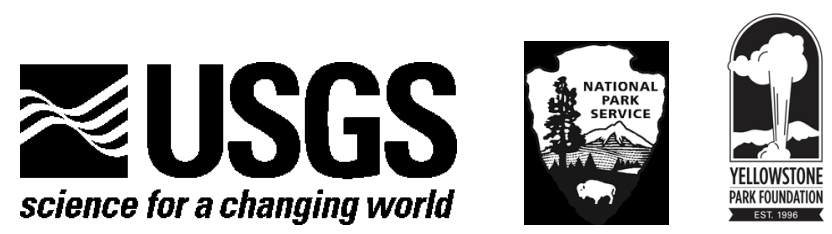

Prepared in cooperation with the National Park Service and the Yellowstone Park Foundation

\title{
Hydrogeology of the Old Faithful Area, Yellowstone National Park, Wyoming, and its Relevance to Natural Resources and Infrastructure
}

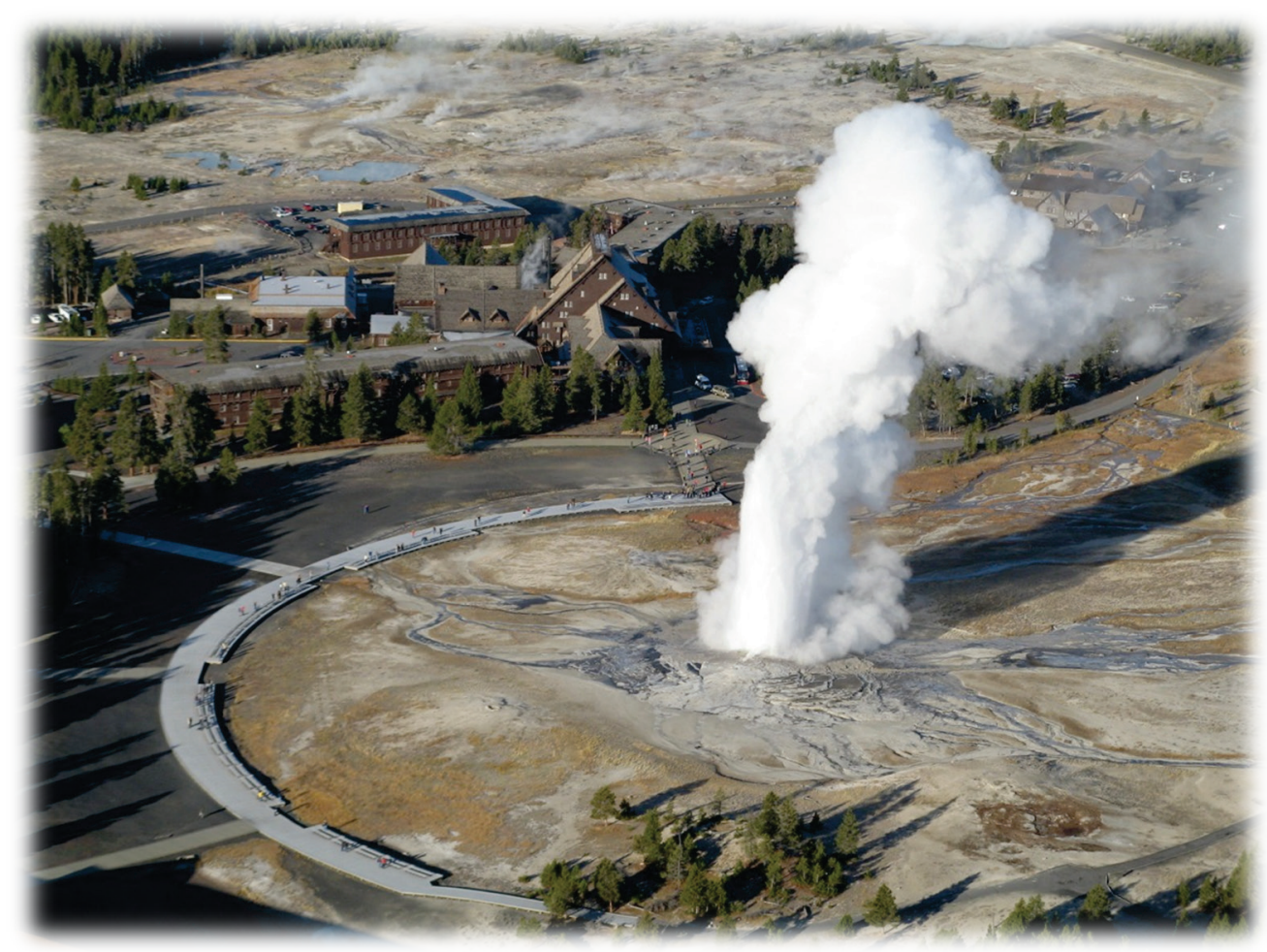

Open-File Report 2014-1058

U.S. Department of the Interior

U.S. Geological Survey 
COVER: Aerial overview of the Old Faithful area from the northeast. (Yellowstone National Park photograph by Cheryl Jaworowski, October 12, 2010.) 


\section{Hydrogeology of the Old Faithful Area, Yellowstone National Park, Wyoming, and its Relevance to Natural Resources and Infrastructure}

By Old Faithful Science Review Panel

Composed of Duncan Foley, Robert O. Fournier, Henry P. Heasler, Bern Hinckley, Steven E. Ingebritsen, Jacob B. Lowenstern, and David D. Susong

Prepared in cooperation with the National Park Service and the Yellowstone Park Foundation

Open-File Report 2014-1058

U.S. Department of the Interior

U.S. Geological Survey 


\section{U.S. Department of the Interior \\ SALLY JEWELL, Secretary}

\section{U.S. Geological Survey \\ Suzette M. Kimball, Acting Director}

U.S. Geological Survey, Reston, Virginia: 2014

For more information on the USGS—-the Federal source for science about the Earth, its natural and living resources, natural hazards, and the environment-visit http://www.usgs.gov or call 1-888-ASK-USGS

For an overview of USGS information products, including maps, imagery, and publications, visit $h$ ttp://www.usgs.gov/pubprod

To order this and other USGS information products, visit $h$ ttp://store.usgs.gov

Suggested citation:

Old Faithful Science Review Panel, 2014, Hydrogeology of the Old Faithful Area, Yellowstone National Park, Wyoming, and its Relevance to Natural Resources and Infrastructure: U.S. Geological Survey Open-File Report 2014-1058, 28 p., http://dx.doi.org/10.3133/ofr20141058..

ISSN 2331-1258 (online)

Any use of trade, firm, or product names is for descriptive purposes only and does not imply endorsement by the U.S. Government.

Although this information product is in the public domain, permission must be secured from the individual copyright owners to reproduce any copyrighted material contained within this report. 


\section{Contents}

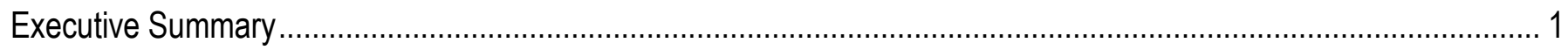

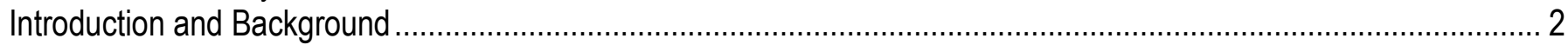

1.0 Geology and Hydrology of Old Faithful and the Upper Geyser Basin ....................................................... 3

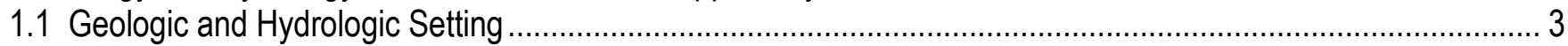

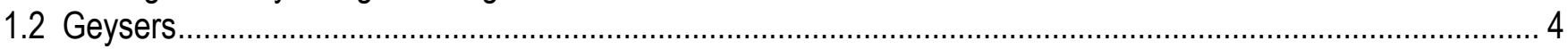

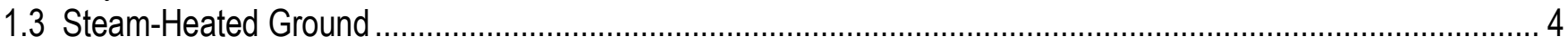

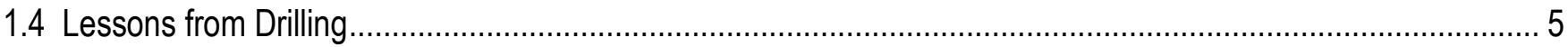

1.5 Thermal Areas at Yellowstone National Park Are Naturally Dynamic and Unstable......................................... 5

1.6 Eruption Behavior of Old Faithful Has Been Changing .......................................................................... 6

1.7 Infrastructure and Thermal Areas Inevitably Affect Each Other ................................................................ 7

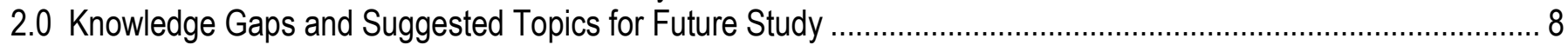

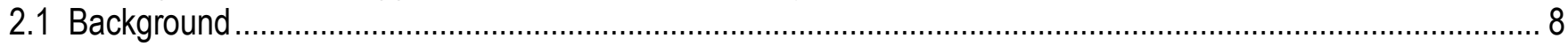

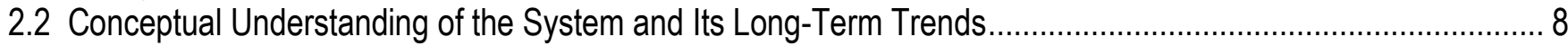

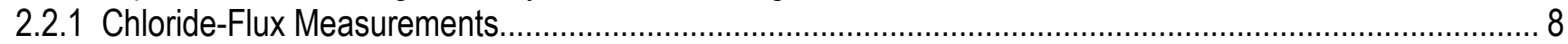

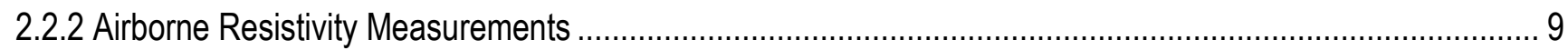

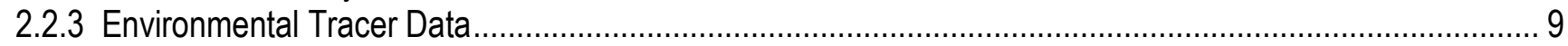

2.2.4 Geyser Frequency and Fluid Discharge Data..............................................................................

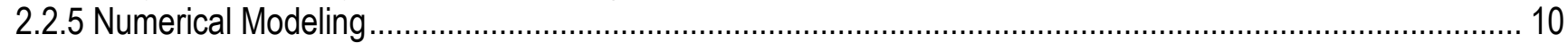

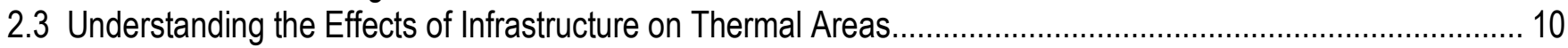

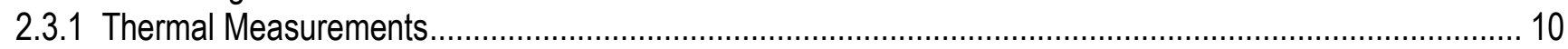

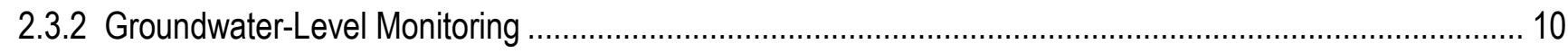

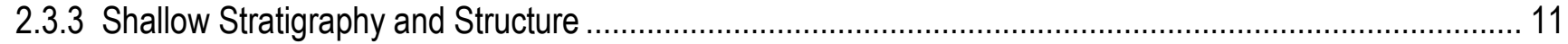

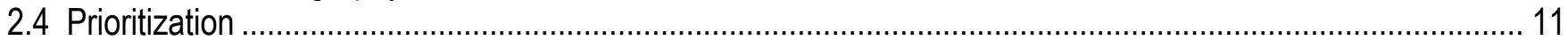

3.0 Guidelines for Infrastructure Management in the Old Faithful Hydrothermal Area ........................................... 12

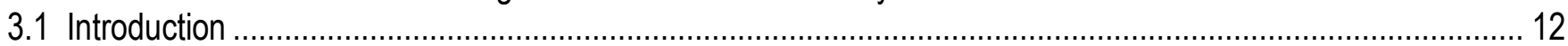

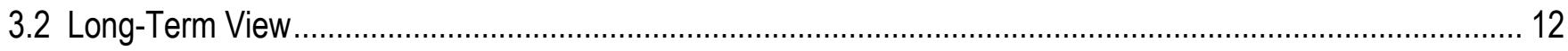

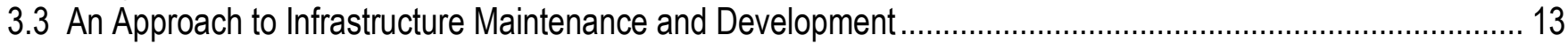

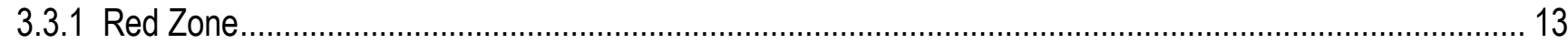

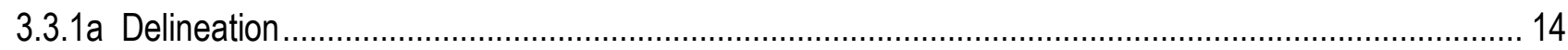

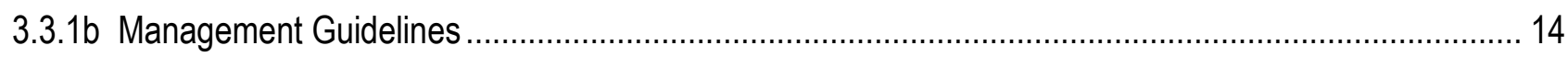

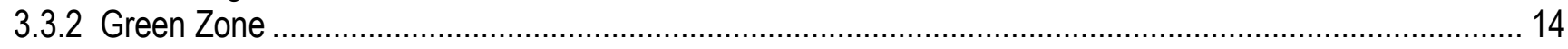

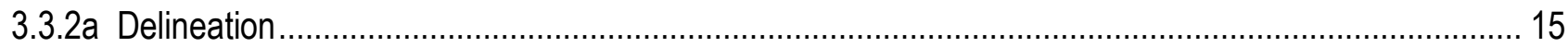

3.3.2b Management Guidelines .................................................................................................... 15

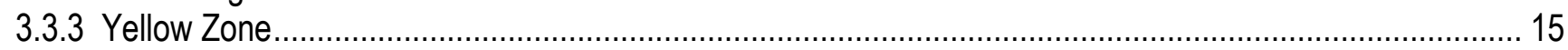

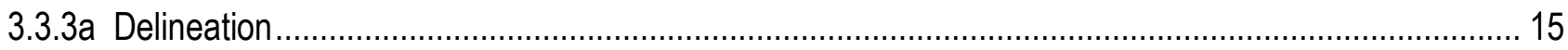

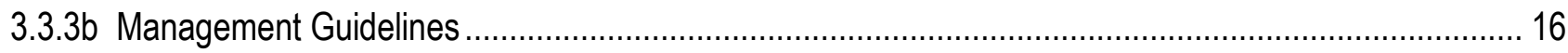

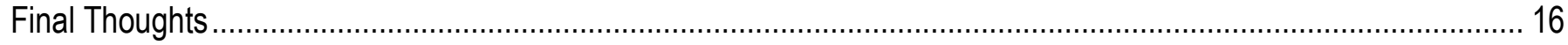

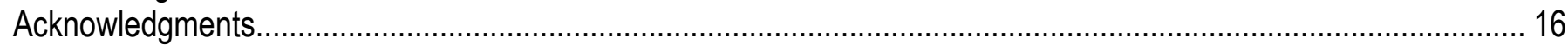

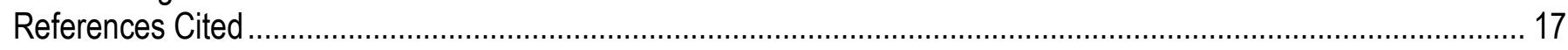

Appendix 1. Legal Mandates, Authorities, and Policies Governing the Protection of Geothermal Resources in

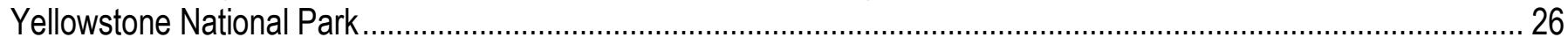

Appendix 2. Presentations to the Old Faithful Science Review Panel, June 3-4, 2013 .......................................... 28 


\section{Figures}

Figure 1. Geologic map of Old Faithful area. The Mallard Lake, Summit Lake, and Scaup Lake lava flows surround the Upper Geyser Basin .....

Figure 2. Schematic cross section along a 5-kilometer profile from southwest to northeast through the Upper Geyser Basin 21

Figure 3. Photograph montage of various types of sediments and hydrothermal deposits

in the Old Faithful area 22

Figure 4. Boxplot showing increase in the eruption interval of Old Faithful from 1960 to the present. 23

Figure 5. Map of the Old Faithful area delineating zones for the protection of the hydrothermal resource and infrastructure.

\section{Table}

Table 1. Proposed Zone System for Old Faithful Area 25 


\section{Conversion Factors and Datum}

\section{Conversion Factors}

SI to Inch/Pound

\begin{tabular}{lcl}
\hline \multicolumn{1}{c}{ Multiply } & By & \multicolumn{1}{c}{ To obtain } \\
\hline centimeter $(\mathrm{cm})$ & Length & \\
meter $(\mathrm{m})$ & 0.3937 & inch (in.) \\
kilometer $(\mathrm{km})$ & 3.281 & foot $(\mathrm{ft})$ \\
\hline & 0.6214 & mile $(\mathrm{mi})$ \\
\hline square meter $\left(\mathrm{m}^{2}\right)$ & Area & \\
square meter $\left(\mathrm{m}^{2}\right)$ & 0.0002471 & acre \\
\hline & 10.76 & square foot $\left(\mathrm{ft}^{2}\right)$ \\
\hline liter $(\mathrm{L})$ & Volume & \\
\hline & 0.2642 & gallon $(\mathrm{gal})$ \\
\hline liter per minute $(\mathrm{L} / \mathrm{m})$ & Flow rate & \\
\hline
\end{tabular}

Temperature in degrees Celsius $\left({ }^{\circ} \mathrm{C}\right)$ may be converted to degrees Fahrenheit $\left({ }^{\circ} \mathrm{F}\right)$ as follows: ${ }^{\circ} \mathrm{F}=\left(1.8 x^{\circ} \mathrm{C}\right)+32$.

\section{Datum}

Horizontal coordinate information is referenced to North American Datum of 1983 (NAD 83). 


\title{
Members of the Old Faithful Science Review Panel
}

\author{
Duncan Foley \\ Professor \\ Department of Geosciences \\ Pacific Lutheran University \\ Tacoma, Washington, 98447
}

Robert O. Fournier

Research Geologist, Retired

U.S. Geological Survey

345 Middlefield Rd.

Menlo Park, California 94025

Henry Heasler

Park Geologist

Yellowstone National Park

P.O. Box 168

Mammoth, WY, 82190

Bern Hinckley

Hinckley Consulting

419 South 5th Street

Laramie, WY 82070

Steven E. Ingebritsen

Research Hydrologist

U.S. Geological Survey

345 Middlefield Rd.

Menlo Park, California 94025

Jacob B. Lowenstern

Research Geologist

U.S. Geological Survey

345 Middlefield Rd.

Menlo Park, California 94025

David D. Susong

Supervisory Hydrologist

U.S. Geological Survey

Utah Water Science Center

2329 Orton Circle

Salt Lake City, UT 84119 


\title{
Hydrogeology of the Old Faithful Area, Yellowstone National Park, Wyoming, and its Relevance to Natural Resources and Infrastructure
}

\author{
By Old Faithful Science Review Panel
}

\section{Executive Summary}

A panel of leading experts (The Old Faithful Science Review Panel) was convened by Yellowstone National Park (YNP) to review and summarize the geological and hydrological understanding that can inform National Park Service management of the Upper Geyser Basin area. We give an overview of present geological and hydrological knowledge of the Old Faithful hydrothermal (hot water) system and related thermal areas in the Upper Geyser Basin. We prioritize avenues for improving our understanding of key knowledge gaps that limit informed decision-making regarding human use in this fragile natural landscape. Lastly, we offer guidelines to minimize impacts to the hydrothermal system that could be used to aid decisions by park management.

Old Faithful sits within the Upper Geyser Basin, an area of abundant hydrothermal activity where boiling waters extend from the surface to significant depth within glacial sediments and underlying volcanic rocks. The geyser systems are directly fed by waters recharged decades to millennia ago, which are surrounded by colder, younger waters. Activity of the geysers is controlled by complex subsurface plumbing with fractures and conduits separated by regions of low permeability. Observations over the past century indicate that the thermal areas and their features are both fragile and highly dynamic. Although Old Faithful has erupted regularly for the past 150 years, it exhibits changes in eruptive behavior over time, and the average interval between eruptions has increased by about 50 percent over the past 50 years. It is clear that human activity has modified the hydrothermal system in the past; conversely, natural features pose ongoing hazards to humans and human infrastructure.

Current (2014) long-term programs to measure heat discharge by chloride-flux monitoring, and more recently by thermal-infrared imaging, are crucial for assessing the status of the hydrothermal system. Complementary studies could include airborne resistivity, environmental tracers, numerical modeling, and greater emphasis on measuring the discharge of water during geyser eruptions. Such data are needed to better understand the subsurface plumbing systems that feed the geysers. Further understanding can be gained through installation of shallow groundwater observation wells, surface geophysical studies, and direct measurement of temperature gradients near the surface. It also is critical to archive existing data from all studies in a manner that will be readily accessible to scientists and decision makers. Monitoring and data collection can be achieved through the YNP geology program, by direct funding to other groups, or by encouraging and facilitating externally funded research. 
There are many documented examples at YNP and elsewhere where human infrastructure and natural thermal features have negatively affected each other. Unless action is taken, human conflicts with the Old Faithful hydrothermal system are likely to increase over the coming years. This is partly because of the increase in park visitation over the past decades, but also because the interval between eruptions of Old Faithful has increased, lengthening the time spent (and services needed) for each visitor at Old Faithful. To avoid an increase in visitor impacts, the National Park Service should consider alternate strategies to accommodate people, vehicles, and services in the Upper Geyser Basin, such as shuttle services from staging (parking and dining) areas with little or no recent hydrothermal activity. We further suggest that YNP consider a zone system to guide maintenance and development of infrastructure in the immediate Old Faithful area. A "red" zone includes hydrothermally active land where new development is discouraged and existing infrastructure is modified with great care. An outer "green" zone represents areas where cooler temperatures and less hydrothermal flow are thought to exist, and where development and maintenance could proceed as occurs elsewhere in the park. An intermediate "yellow" zone would require preliminary assessment of subsurface temperatures and gas concentrations to assess suitability for infrastructure development. The panel recommends that YNP management follow the lead of the National Park System Advisory Board Science Committee (2012) by applying the "precautionary principle" when making decisions regarding the interaction of hydrothermal phenomena and park infrastructure in the Old Faithful area and other thermal areas within YNP.

\section{Introduction and Background}

The Old Faithful area is the pre-eminent location in the world's first National Park and is a unique and globally treasured geological area. Since 1872, park administrators have grappled with the delicate balance of preserving natural features while maximizing the ability of the public to enjoy and explore this natural wonderland. Globally recognized cultural resources also are part of the Old Faithful landscape, including Robert Reamer's 1904 rustic architectural masterpiece, the Old Faithful Inn.

Over the past 50 years, visitation to YNP and Old Faithful has almost doubled, resulting in growing needs for parking, lodging, food service, and other essentials in or near the Upper Geyser Basin. Park administration must frequently consider the tradeoffs involved with simultaneously providing for public enjoyment of the area, maintaining cultural resources, and minimizing impacts to hydrothermal resources (natural hot waters and related thermal features). Similarly, it has been challenging to maintain park infrastructure, especially underground utilities, in areas with abundant natural heat and reactive fluids.

Specific legal mandates address the protection of geothermal and hydrothermal resources in YNP and are reviewed in appendix 1. The legislation creating YNP in 1872 states that the park

"...shall provide for the preservation, from injury or spoliation, of all timber, mineral deposits, natural curiosities, or wonders within said park, and their retention in their natural condition [17 Stat. 32]."

For areas outside the park, directives seek to preclude even the threat of adverse effects on the park's hydrothermal resources. An example is the 1994 establishment of the Yellowstone Controlled Groundwater Area (YCGA) in an area of Montana outside of the park's boundary to "allow no impact to the hydrothermal system within the reserved lands of YNP." 
A panel of leading experts (The Old Faithful Science Review Panel) was convened by YNP to provide a summary of current knowledge of the hydrothermal system and its potential vulnerability to current and future human activities. The panel consists of seven experts on hydrology, geology, and geothermal resources, and met on June 3-5, 2013, at Snow Lodge, near Old Faithful. The panel listened to presentations by a variety of park employees, including managers, law enforcement personnel, and historians, as well as science briefings by panelists and other invited researchers (appendix 2). The panel subsequently communicated through face-to-face meetings, e-mail, and teleconferences to create this report.

In this report, we give an overview of present geological and hydrological knowledge of the Old Faithful hydrothermal area and Upper Geyser Basin. We also prioritize avenues for improving our understanding of key knowledge gaps that limit informed decision-making regarding human use in this fragile natural landscape. Finally, we offer suggestions that may assist with present and future management of hydrothermal resources in the Old Faithful area.

\subsection{Geology and Hydrology of Old Faithful and the Upper Geyser Basin}

\subsection{Geologic and Hydrologic Setting}

Old Faithful and the rest of the Upper Geyser Basin are located in the Firehole River valley. The valley is bordered by young rhyolitic lava flows that erupted 100,000-170,000 years ago and formed the valley margins (fig. 1; Christiansen, 2001). During the last glacial maximum, the area was covered by glacial ice. The glaciers and their meltwater systems deposited up to about $60 \mathrm{~m}(200 \mathrm{ft})$ of sediments on the valley floor (figs. 2 and 3a). These sediments, which were deposited by ice-contact and icemarginal streams, are largely composed of obsidian sand and gravel derived from the local rhyolites (Muffler and others, 1982). The sediments have a wide range of vertical and horizontal permeability in part due to local hydrothermal alteration and cementation by hydrothermal minerals.

The dominant hydrothermal water of Old Faithful and Geyser Hill is neutral to alkaline in $\mathrm{pH}$ and rich in dissolved chloride, silica $\left(\mathrm{SiO}_{2}\right)$, and other elements. Upon cooling at the surface, the water precipitates silica sinter that often forms "aprons" around thermal features (figs. 1 and 3b). Studies of the chemistry and isotopic composition of the thermal waters indicate that the waters ultimately originate as precipitation (rain and snow) but interact with deep rock to gain heat, chloride, and other solutes. The thermal waters contain very little tritium $\left({ }^{3} \mathrm{H}\right)$, a hydrogen isotope created in the atmosphere, which implies very little contribution from waters less than 60 years old (Pearson and Truesdell, 1978; Rye and Truesdell, 2007; Gardner and others, 2011; Hurwitz and others, 2012).

Chemical thermometry of thermal waters discharging in the Upper Geyser Basin indicates that most have resided in the subsurface long enough to attain chemical equilibrium with the surrounding rock in a zone of porous and permeable rock (an underground reservoir) between 170 and $210 \mathrm{~m}$ (560 and $690 \mathrm{ft})$ deep at temperatures around $210^{\circ} \mathrm{C}\left(400^{\circ} \mathrm{F}\right)$, as discussed in Dr. Robert Fournier's ${ }^{1}$ presentation to the panel on June 3, 2013, and detailed in Fournier (1989). These thermal waters

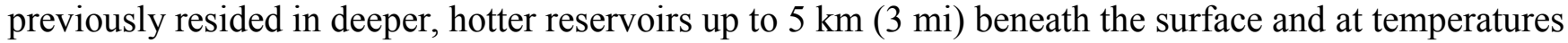
estimated at $350^{\circ} \mathrm{C}\left(660^{\circ} \mathrm{F}\right)$. Steep faults and fractures guide the thermal water upward toward the

\footnotetext{
${ }^{1}$ The talks were recorded and saved as digital video available from YNP.
} 
surface - thermal water is discharged in the topographically low region of the Upper Geyser Basin (fig. 2) at a significant time and distance from its area of infiltration as dilute rain. A National Park Service (NPS) chloride-flux monitoring program permits quantification of the combined mass of thermal water discharged into the Firehole River from the Upper and Lower Geyser Basins. This program provides a means of evaluating changes in the total output of thermal fluids and heat by the hydrothermal system that might result from large earthquakes, climate change or human activity (Friedman and Norton, 2007; Hurwitz and others, 2007).

\subsection{Geysers}

Geysers intermittently erupt jets of water. At YNP, geyser eruptions are initiated when water in a geyser conduit starts to boil vigorously. The expansion of steam powers the discharge. The geysering requires temporary over-pressures created during repeated cycles of reheating by superheated waters. A critical requirement for long-lasting activity of a geyser is the maintenance of appropriate permeability within the geyser conduits relative to the surrounding rocks. Permeability is decreased by precipitation of amorphous silica and other mineral deposits during cooling of thermal water. Permeability increases through the action of earthquakes or powerful geyser eruptions that can break the rocks. Limited exploration with video cameras, thermometers, and geophysical techniques indicates that the uppermost part of Old Faithful Geyser's feeder tube is an irregular fissure with open cavities separated by narrow slots or throttles that limit the ease of fluid flow (Hutchinson and others, 1997). The volume of water in a newly discovered elongated cavity at the side of Old Faithful (Vandemeulebrouck and others, 2013) has been estimated at $62,000 \mathrm{~L}(16,500 \mathrm{gal})$, equivalent to the volume of a sphere about $5 \mathrm{~m}(16 \mathrm{ft})$ in diameter. This does not include the considerable amount of water in the actual geyser tube. A tracer test conducted in the Daisy Group of geysers in the 1960s indicated that the reservoir supplying water to Splendid Geyser holds more than 270,000 L (71,000 gal) of thermal water (Rowe and others, 1965). Little other work has been done to explore the subsurface "plumbing" of YNP geysers.

\subsection{Steam-Heated Ground}

Subsurface boiling inevitably causes migration of steam. When the steam reaches the periphery of a thermal area and cools, it will condense beneath the ground surface to create steaming ground as found at the margins of the Myriad Group near the Laurel Dorm (fig. 3c). Alteration of near-surface sediment in steam-heated zones can create oxidized zones of low-permeability red clays (fig. 3d). These clay zones often overlie zones of steam condensation and play an important role in minimizing the migration of thermal waters and gases. The exact margins of steam-heated areas may be difficult to delineate by eye, particularly where sinter has been deposited on the ground or the ground has been disturbed by human activities. Regions affected by hydrothermal alteration have been mapped with hyperspectral airborne techniques (Livo and others, 2007), as well as field mapping (Muffler and others, 1982). 


\subsection{Lessons from Drilling}

Much of our understanding of the subsurface beneath the Upper Geyser Basin comes from scientific drilling discussed in Dr. Jacob Lowenstern's presentation on June 3, 2013. One hole was drilled by the Carnegie Institute in 1929 (C-1 in the Myriad Group; Fenner, 1936), and three by the U.S. Geological Survey (USGS) in 1967 (Y-1 in Black Sand Basin; Y-7 and Y-8 in Biscuit Basin; fig. 1). A total of 13 wells were drilled in YNP by the USGS in 1967-68 (White and others, 1975). Investigations of these wells involved downhole temperature and pressure measurements, fluid sampling, and coring of subsurface rocks. Lessons from the drilling included:

1. In active thermal areas, subsurface water temperatures increased along the boiling-point curve, as pressure increased with depth.

2. Water pressures in the channels of hydrothermal convective up-flow were approximately equal to or greater than those in the adjacent cold groundwater that surrounded the geyser basins. This prevents surrounding cold waters from entering upflow channels that feed geysers.

3. When a well discharging boiling water and steam was "shut," steam and non-condensable gas immediately started to accumulate beneath the valve, resulting in a rapid and significant increase in pressure at the wellhead.

4. In the Upper Geyser Basin, glacial sediments in the wells were less than $60 \mathrm{~m}$ (200 ft) thick; at greater depths, the wells encountered rhyolite flows. The sediment thickness ranges greatly due to the original uneven topography prior to deposition of sediments.

5. Drilling close to Whistle Geyser temporarily affected its output and behavior (White, 1991).

\subsection{Thermal Areas at Yellowstone National Park Are Naturally Dynamic and Unstable}

Thermal features and their feeders change and shift location through time. Some geysers have ceased erupting for unknown reasons. Others have ceased erupting for long periods and then restarted. For example, intervals between major eruptions of Steamboat Geyser (Norris Geyser Basin) have ranged from 4 days to 50 years. The interval preceding the major eruption of Steamboat Geyser on July 31, 2013, was 8 years. Slight changes in behavior of nearby springs and geysers can have major effects. For example, in the early 1960s, Daisy Geyser (Upper Geyser Basin) ceased erupting, while simultaneously a previously insignificant nearby spring (Bonita) began to discharge at an increased rate. A short-term experiment showed that temporarily increasing the level at which water flowed from Bonita by $8-10 \mathrm{~cm}$ (3-4 in.) could induce eruptions of Daisy Geyser. This illustrates that thermal features can be sensitive to small pressure changes from nearby pools or geysers, and suggests sensitivity to small changes in local groundwater levels and recharge.

Hydrothermal explosions (rock-hurling eruptions) have occurred numerous times at YNP, both during historic times and in the geological record (Christiansen and others, 2007; Morgan and others, 2009). Some occur when natural throttles (narrow constrictions in the path of fluid flow) rupture, resulting in a decrease in pressure and an immediate flashing of some liquid water to steam. The hydrothermal explosion in 1989 at Porkchop Geyser in Norris Geyser Basin is particularly well documented (Fournier and others, 1991). Throttles may fail for many reasons, including seismic activity or a disturbance by drilling or digging. Most deep hot spring pools in YNP likely result from relatively small hydrothermal explosions. The most notable examples of large hydrothermal explosions near Old 
Faithful are the 1880s explosions at Excelsior Geyser in Midway Geyser Basin and the 1959 activity at Sapphire Pool, which continues intermittently in nearby pools at Biscuit Basin. Prehistoric explosions

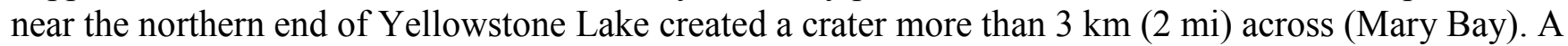
1-km-diameter crater (0.6 mi) was formed about 11,000 years ago in Pocket Basin in the Lower Geyser Basin, likely due to depressurization associated with draining of a glacial lake (Muffler and others, 1971).

The effects of strong earthquakes on hot spring and geyser activity in the Upper Geyser Basin have been well documented (Marler, 1964). Six days after the 1959 M7.5 Hebgen Lake earthquake, Sapphire Pool in Biscuit Basin erupted with violent force, throwing large blocks of sinter into the air, greatly enlarging its pool, and issuing a wave of water over the adjacent boardwalk. If anyone had been present, it is likely that they would have been fatally scalded. For about 2 years thereafter, Sapphire Pool erupted a few times a day to a height of about $45 \mathrm{~m}(150 \mathrm{ft})$, before its throat became enlarged to such an extent that it could no longer erupt. In contrast, after the same earthquake, it took 2.5 years for Seismic Geyser to evolve from a new crack in sinter to a small geyser, and still more years for that geyser to reach heights of 12-15 m (40-50 ft). Its eruptions ceased when a small nearby thermal feature became active (Marler and White, 1975).

The ground surface at YNP has many sinter-covered areas formed by earlier stages of hydrothermal activity. Many of these areas are now covered with forests or other vegetation (Fournier, 1989). However, hydrothermal activity can rejuvenate unexpectedly in such places. Current scientific knowledge is insufficient to predict when or where shifts in activity may take place. Most recent changes have been clearly tied to earthquakes or swarms, as with the 1959 Hebgen Lake earthquake, or the earthquake swarm in 1978 that caused changes to Cooking Hillside at Mud Volcano (Evans and others, 2010). However, changes may occur simply because of the complexity of the numerous subsurface cracks, caverns, and mineralized seals.

\subsection{Eruption Behavior of Old Faithful Has Been Changing}

The average interval between eruptions of Old Faithful Geyser has been getting longer, with noticeable increases in both the average and maximum interval. Intervals have changed from an average of about 66 minutes in the 1960s to more than 90 minutes in 2013 (fig. 4).

The average interval between eruptions of Old Faithful is affected by local and distant seismic events (Marler, 1964; Husen and others, 2004) and also may be affected by changes in the depth to the local water table. Decreased groundwater pressure implies a longer recharge time for a geyser eruption. In the absence of actual groundwater monitoring wells, the only indicator of groundwater elevation or pressure is the flow of the Firehole and Madison Rivers. There is a correlation between Old Faithful's average annual eruption interval and variations in the flow of the Madison River, suggesting that variations in the water table may be responsible (Hurwitz and others, 2008). Similar correlations were found with the eruption intervals of Daisy, Aurum, and Depressions Geysers in Upper Geyser Basin. Long-term precipitation and impacts on the local water table are almost certainly factors in the behavior of Old Faithful and other geysers.

It is quite possible that the total mass of water erupted from Old Faithful has decreased as the average interval between eruptions has increased. However, there have not been measurements of the actual discharge associated with eruptions, and it is difficult to evaluate long-term changes of Old Faithful without a complete understanding of the total water and heat budget of the eruptions. 
Although Old Faithful has been erupting about every 1-2 hours since the founding of the park, the progressive increase in the time between eruptions, and the history of other geysers, suggest that it will not do so indefinitely. Future projections of the average eruption interval are not reliable. Because of the complexity of the natural system, it can be concluded that further changes and even cessation of Old Faithful eruptions are possible. Logs and stumps found buried in sinter on the geyser mound suggest that Old Faithful was completely inactive a few hundred years ago (Bauer and Marler, 1939).

\subsection{Infrastructure and Thermal Areas Inevitably Affect Each Other}

There is potential for anthropogenic disruption of existing hydrothermal features, including Old Faithful. For example, diversion of river water for consumptive use, paving for roads and parking lots, and the footprint of new buildings can decrease the amount of recharge into the groundwater system. Trenches for sewage, electricity, gas, and other infrastructure can change the pathways for movement of heat and groundwater. Such changes are evident in the aerial thermal infrared (TIR) images collected by the NPS that were shown to the panel by Dr. Cheryl Jaworowski on June 4, 2013, which demonstrate heat anomalies from buried pipelines. There are places in YNP where park infrastructure has impacted hydrothermal features, in some cases catastrophically. For example, in the 1960s, the excavation of the footing for the main support of the Old Faithful overpass intercepted very hot water that flowed at a rate of about 150-190 L/min (40-50 gal/min). Nearby hot springs simultaneously dried up. Stopping this discharge of thermal water and gas with a cement plug was considered and rejected because the plug might cause $\mathrm{H}_{2} \mathrm{~S}$-rich gas to accumulate under the plug, and then leak around its sides. The $\mathrm{H}_{2} \mathrm{~S}$ would then react with water to form sulfuric acid, which would attack both the bridge support and cement plug until the plug failed. This would result in near-boiling water cascading over the road. The approach devised to allow construction of the overpass to continue was to divert the flow of this water into a new culvert so that it could discharge freely from beneath the road about $300 \mathrm{~m}(980 \mathrm{ft})$ to the west.

The Laurel Dorm, located behind the Old Faithful Inn, is at the edge of a zone of hot ground, with mitigation required to ensure the health of the building and its inhabitants (Heasler and Jaworowski, 2011a). The historic Old Faithful Pub, located nearby, was seriously impacted by hydrothermal activity, which ultimately resulted in its demolition (Heasler and others, 2009a, 2009b). The lifetimes of buildings and pipes in corrosive thermal environments are certainly reduced relative to similar structures in non-thermal areas. There probably are places in Upper Geyser Basin where such impacts are yet to be detected or understood.

The cumulative effect of park infrastructure on the Old Faithful hydrothermal system is difficult if not impossible to assess. Airborne TIR imagery clearly shows that trenching has altered the natural surface temperature pattern in the Old Faithful developed area (Heasler and Jaworowski, 2011b). Any specific connection between such changes and the behavior of thermal features is difficult to quantify. At this time, scientific data do not exist that allow us to say with any degree of confidence that existing and past roads, parking lots, buildings, and subsurface infrastructure have, or have not, affected Old Faithful and other features in the Upper Geyser Basin. Scientific data can assist the park in gaining an understanding of the nature of the changes that are occurring, how these changes compare in magnitude to previous changes, and how the impacts of future infrastructure development and maintenance might be minimized. 


\subsection{Knowledge Gaps and Suggested Topics for Future Study}

\subsection{Background}

Infrastructure within developed areas at Old Faithful may affect the hydrothermal system directly (for example, by trenching in sinter aprons) or indirectly by intercepting groundwater recharge, redirecting fluids and heat, and otherwise changing the heat and pressure distribution in, around, and above the hydrothermal system.

In order to evaluate the impact of the developed areas on hydrothermal systems, it is crucial to understand the distribution of fluids and heat in the shallow subsurface (upper $10 \mathrm{~m}$ or $33 \mathrm{ft}$ ). In order to evaluate the causes of long-term trends in the behavior of thermal features, it also is crucial to understand the larger system that contributes water and heat, including the relationship between the shallow groundwater system and upwelling plumes of hot water. NPS staff and others are already collecting relevant monitoring data in the Old Faithful area, and these data provide important information for assessment of the hydrothermal system. These efforts include chloride-flux monitoring on the Firehole River, geyser-eruption monitoring, acquisition and analysis of TIR data, and ground heat flux and temperature monitoring in conjunction with various infrastructure projects and issues. Many of these ongoing efforts are described in "A Hydrothermal Monitoring Plan for Yellowstone National Park" (Heasler and others, 2004). In this section, we suggest additional data that could contribute to the understanding of relatively local impacts, the larger flow system, or both. We assess the relevance of these data to identifying and/or mitigating impacts, and discuss prioritization of additional data collection. The park may choose to foster such research through facilitating externally funded research projects, or it could utilize either YNP staff or contracted scientists.

Relevant existing data should be thoroughly exploited. We suggest that a comprehensive assessment of available information should accompany acquisition of new data. To cite one example: continuous geyser-frequency and eruption-duration data for Old Faithful are available for approximately the past 10 years. These data may have implications for trends in geyser mass discharge, and the data should be examined in this light. We also suggest, for instance, systematic efforts to catalog information from excavations and borings, and development of a comprehensive database of information acquired from hydrothermal-research and infrastructure maintenance efforts. We realize that this is a difficult task and something that will take time and funding.

\subsection{Conceptual Understanding of the System and Its Long-Term Trends}

\subsubsection{Chloride-Flux Measurements}

The panel commends the longstanding monitoring of chloride flux in the major rivers of YNP and recommends that it be continued. Thermal water is the predominant source of chloride in rivers at YNP. Thus, the multi-decadal chloride-flux dataset can be used to evaluate trends in discharge from the hydrothermal system. Moreover, the thermal water discharge is a proxy for total heat flux, and permits evaluation of the potential response of the hydrothermal system to tectonic activity, climate change, or anthropogenic activities (Fournier and others, 1976; Ingebritsen and others, 2001; Freidman and Norton, 2007; Hurwitz and others, 2007). Existing data have been interpreted as indicating a long-term decline in hydrothermal discharge (Friedman and Norton, 2007), although not all investigators agree (Ingebritsen and others, 2001; Hurwitz and others, 2007) and additional years of similar data are needed. 
At present, the USGS streamgage in the Firehole Canyon monitors the cumulative chloride flux from all the geyser basins in the Firehole River drainage basin (McCleskey and others, 2012). More intensive chloride-flux monitoring on shorter river reaches in the Upper Geyser Basin could improve understanding at the individual geyser-basin scale for possible correlation with site-specific management activities. For example, one could quantify the total output of thermal fluid from the Upper Geyser Basin rather than the entire Firehole River.

\subsubsection{Airborne Resistivity Measurements}

Discharge from the hydrothermal system is well monitored by the chloride-flux network and, increasingly, by gas-discharge and heat-flow measurements. However, long-term conservation also requires knowledge of the origins and flowpaths of upwelling hydrothermal fluids. The presentation to the panel by Dr. Rick Allis on June 3, 2013, demonstrated the utility of airborne resistivity measurements to image/map upflow plume(s) in the Taupo Volcanic Zone, New Zealand-a geologically similar environment. A useful target depth for such measurements, per the New Zealand example, would be 200-500 m (650-1640 ft). Understanding the flowpaths of hydrothermal fluids could provide critical information for assessing vulnerability of the hydrothermal system to anthropogenic impacts.

\subsubsection{Environmental Tracer Data}

The presentation to the panel by Dr. Payton Gardner on June 3, 2013, illustrated the utility of isotopic and chemical tracers for understanding flow, mixing, connectivity, and groundwater dynamics adjacent to the Norris Geyser Basin (Gardner and others, 2011). A similar dataset in the Upper Geyser Basin area could provide new insights into the sources, flow paths, and residence times of fluids in both the hydrothermal system and the cold groundwater system, and about the extent of mixing between these systems. Residence-time and flow-path information is important for assessing impactsparticularly indirect impacts that may not manifest themselves immediately. For example, if groundwater recharge were impeded due to surface pavement, how long would it take to impact the hydrothermal system?

\subsubsection{Geyser Frequency and Fluid Discharge Data}

Geyser eruptive behavior and the nuances of particular hydrothermal features are of great interest to geyser enthusiasts and members of the public. The current geyser monitoring program by NPS (using temperature data loggers in outflow channels) provides a general record of system dynamics. In addition to eruption monitoring, periodic measurements of fluid discharge from Old Faithful would provide valuable information useful for assessing changes to the geyser, conceptualizing the geyser, and constraining numerical models. Despite the iconic status of Old Faithful, there has been only a single measurement of fluid discharge (in the 1960s; Kieffer, 1984). Does the lengthening of eruption intervals correspond to a decrease in the total discharge of water from Old Faithful? In other words, is less water available to erupt, or is the same amount of water erupting in larger, less frequent bursts? On the basis of existing information, it is impossible to determine whether the total discharge from Old Faithful is changing. This makes it difficult to assess whether the long-term changes in eruptive behavior are related to local anthropogenic impacts or regional meteorological or hydrologic factors. 


\subsubsection{Numerical Modeling}

A numerical model of Old Faithful Geyser and its nearby surroundings could be developed and updated with new information to serve as both a scientific and educational tool. The existence of such a model would promote hypothesis testing and system conceptualization. However, because of the high degree of non-uniqueness inherent to such models, it would be unlikely to serve as a predictive tool for management in the foreseeable future.

\subsection{Understanding the Effects of Infrastructure on Thermal Areas}

\subsubsection{Thermal Measurements}

Heat-flow measurements at hydrothermal areas have been done at many sites worldwide (particularly in United States, New Zealand, Italy, and Japan) to enhance understanding of fluid and heat flow. Despite the global significance of the Old Faithful area, such comprehensive measurements have rarely been made here. Presentations to the panel on June 4, 2013, clearly documented the relevance of thermal data to Old Faithful infrastructure-management issues. In the TIR images, underground utilities were clearly visible in some areas, and hot ground was shown adjacent to buildings, paths, and boardwalks (Heasler and Jaworowski, 2011b). We recommend that efforts to collect thermal data be continued and systematically expanded. This category includes satellite and airborne TIR data; very shallow (about $15 \mathrm{~cm}$ or 6 in) temperature surveys, and deeper (about $1 \mathrm{~m}$ or $3 \mathrm{ft}$ ) temperature surveys that would permit quantification of heat flow. The purpose of such shallow holes is not to define deep conductive gradients, but rather to identify hot or gassy areas adjacent to infrastructure. Each of the above methods has particular strengths. TIR surveys provide synoptic data over a large area and can be systematically repeated to detect changes. Very shallow temperature surveys can cover large areas (hundreds of square meters) and can be quantitatively converted to heat flow where heat-flow values are sufficiently high and seasonal and diurnal temperature variations are negligible or accounted for. The more time-consuming deeper (about $1 \mathrm{~m}$ or $3 \mathrm{ft}$ ) measurements permit heat-flow to be quantified in cooler areas. Lessons learned from geothermal development in New Zealand demonstrates that heatflow data can provide useful quantitative guidelines for infrastructure development and can form the basis for delineating management zones (Dickie and Luketina, 2005). This type of data collection in a developed area like Old Faithful is complicated by the amount of impervious surface (pavement and sinter aprons).

\subsubsection{Groundwater-Level Monitoring}

The hydrothermal systems in YNP are linked to shallow non-thermal groundwater systems by direct fluid flow and mixing and by pressure responses. Pressure response can propagate long distances in the subsurface. Such linkages constitute the technical and philosophical basis for groundwater protection adjacent to the Park as reflected in the Water Rights Compact between the State of Montana and the United States of America, National Park Service, as well as State of Wyoming legislation, and the withdrawal of federal lands from geothermal leasing in the Island Park Known Geothermal Resource Area. Similar groundwater and geothermal protection protocols do not currently (2014) exist within YNP. The only existing groundwater-monitoring wells in the Old Faithful area are those associated with lagoons at the sewage-treatment plant. The panel recommends that shallow monitoring wells be 
installed within the Old Faithful developed area. Such wells would provide baseline data on water-table levels, chemistry, and temperature in the shallow subsurface. The resulting data could be combined with precipitation data to investigate linkages among rainfall, cold groundwater levels, and hydrothermal discharge, thus helping to assess the effects of paved surfaces on the local hydrology.

\subsubsection{Shallow Stratigraphy and Structure}

There is very limited information on the shallow stratigraphy of glacial and alluvial sediments within the Upper and Lower Geyser Basins because of the lack of wells and the scarcity of geophysical surveys. Vandemeulebrouck and others (2013) described the conduits feeding Old Faithful Geyser, demonstrating the potential utility of geophysics in understanding the shallow subsurface. Several noninvasive geophysical methods (from electromagnetic to ground-penetrating radar) are widely used to investigate shallow subsurface stratigraphy and structure. Some of these techniques might be used to map the type and extent of geologic materials, identify conduits feeding key hydrothermal features, and assess the effects of buildings and paved surfaces on groundwater recharge. The panel encourages the NPS to seek collaborative opportunities to obtain geophysical surveys to address specific concerns about the shallow subsurface in the Old Faithful area. The shallow groundwater monitoring wells described in Section, "2.3.2, Groundwater-Level Monitoring," also would contribute information on the location and characteristics of geological materials and fluids in the Old Faithful area.

\subsection{Prioritization}

The panel discussed prioritization of ongoing and prospective hydrothermal monitoring and research. Following this discussion, we can suggest only general guidelines. There are several elements to consider: (1) usefulness in terms of immediate infrastructure-planning and infrastructure-management needs, (2) usefulness in terms of conceptual understanding of the hydrothermal system (and thus longerterm infrastructure planning), and (3) cost. Development of an Old Faithful-specific hydrothermal monitoring plan would be a valuable exercise that could add specificity to monitoring activities, assist in prioritization, and address data storage and maintenance issues.

We attach particularly high priority to comprehensive assessment and archiving of existing data, continued chloride-flux and geyser-frequency monitoring, and systematic thermal measurements (including TIR). Valuable and relatively low-cost additions would include installation of a network of shallow piezometers (groundwater pressure indicators) in the Old Faithful developed area. The panel notes that, at least in the United States, abundant piezometer data are collected in nearly all cases where groundwater impacts are at issue. Another low-cost monitoring target is periodic measurement of mass discharge from Old Faithful. Surficial and airborne geophysical data could be acquired opportunistically as potential collaborators come forward to do the work. 


\subsection{Guidelines for Infrastructure Management in the Old Faithful Hydrothermal Area}

\subsection{Introduction}

The objective of this section is to provide suggestions for management of the Old Faithful area that incorporate our current understanding of the local geology and hydrology. Recognizing that there are a host of related issues regarding cultural resources, facilities maintenance, traffic control, visitor services, and law enforcement—all of which require thoughtful balancing and prioritization—our focus here is on management of the interactions between infrastructure and the hydrothermal system. With respect to infrastructure, the goal is to maximize the long-term integrity, utility, and safety of park investments. With respect to the hydrothermal system, the goal is to maximize the protection of natural processes and features while also maintaining visitor access.

Prior to delving into details, it is appropriate to highlight pertinent lessons from Section 1.0, "Geology and Hydrology of Old Faithful and the Upper Geyser Basin" and 2.0, "Knowledge Gaps and Suggested Topics for Future Study." Old Faithful is in the Upper Geyser Basin, one of three major geyser basins along the Firehole River (the others being the Midway and Lower Geyser Basins to the north). Even though thermal waters emerge only at discrete locations within these basins, they can be found throughout the basins at depth, even beneath nominally cold ground. The pathways of water flow and discharge change with time in a complex manner that responds to long-term groundwater recharge, earthquakes, buildup of natural mineral deposits in flow channels, and human developments.

Occasionally, the changes may be explosive in nature if a natural throttle fails and hot water is rapidly depressurized. Subterranean activity occasionally results in the formation of shallow subsurface cavities that can further compromise buildings and infrastructure. Compared with most cold groundwater aquifers that are more spatially homogeneous and predictable, hydrothermal systems are highly varied in structure and permeability. Old Faithful was previously non-erupting, as indicated by fossil trees that have been covered with silica deposits. Over the past 50 years, the eruption interval of Old Faithful has slowly changed, increasing the mean time interval between eruptions from around 60 to more than 90 minutes. This change possibly could be related to a gradual decrease in the permeability of the geyser conduit, long-term decreases in rainfall and groundwater recharge, earthquakes, an increase in impermeable areas associated with buildings, parking areas and roads, or some combination thereof.

\subsection{Long-Term View}

Current (2014) trends in visitation suggest that increasingly more people will desire to visit Old Faithful in future years. If the geyser continues to erupt less frequently, each visitor will need to spend additional time waiting and using services. The NPS can choose to slowly increase parking, food services, sanitation, and other infrastructure needed to accommodate the increasing number of visitors. Alternatively, NPS can start to evaluate the potential impacts of existing development and the limits beyond which further development would be undesirable. 
An overall guiding principle for the NPS is clearly expressed in "Revisiting Leopold: Resource Stewardship in the National Parks" (National Park System Advisory Board Science Committee, 2012, p. 14):

"Because ecological and cultural systems are complex, continuously changing and not fully understood, NPS managers and decision makers will need to embrace more fully the precautionary principle as an operating guide."

Faced with considerable uncertainty, and given the high value placed on hydrothermal features in the Old Faithful area, we encourage application of the precautionary principle and emphasize the important role of science in informed stewardship. YNP has entered into compacts with surrounding States for management of hydrothermal features, which compel the States, even in cases where impacts on YNP hydrothermal features may be unknown, to do no harm to the features. A similar standard could logically be applied to areas within the YNP. Both the natural and institutional contexts exist in a world that is undergoing, "...continuous change that is not yet understood." (National Park System Advisory Board Science Committee, 2012, p. 11.)

We suggest that the NPS consider mechanisms to mitigate the impacts of current (2014) and continuously increasing visitation on this fragile natural area. Many parks have successfully used shuttle services that reduce congestion and the need for increased parking and infrastructure. The lava plateaus just outside the thermal basins are geologically stable, lack hydrothermal features, and provide few hindrances to infrastructure development. Such areas could serve as staging grounds for visitors, thereby avoiding the need for additional visitor services or allowing for the reduction of services in the Old Faithful area.

\subsection{An Approach to Infrastructure Maintenance and Development}

We propose an approach to balancing protection of the hydrothermal system with infrastructure needs in the Old Faithful area. Our example uses a "zone" system designed to reduce the impacts to the hydrothermal system by infrastructure and conversely reduce the impacts to infrastructure by the hydrothermal system.

Delineation criteria and recommended management guidelines for each zone are shown in table 1. We emphasize that as additional information is developed (see Section 2.0 Knowledge Gaps and Suggested Topics for Future Study), both the delineations and suggested guidelines should be reviewed and adjusted as appropriate. The zone concept is offered as one potential method to reduce the risk of permanently impairing the Old Faithful hydrothermal system and of increasing the longevity, integrity, and long-term utility of developed infrastructure. The zone definitions and suggested guidelines are preliminary in nature. Details for specific implementation of this strategy could be provided as needed by a working group specifically tasked with such a purpose.

\subsubsection{Red Zone}

The red zone encompasses areas with active hydrothermal activity or with high potential for hydrothermal activity that can negatively impact infrastructure, or vice versa. Although additional scientific investigation could add to our understanding of these areas, sufficient information is currently available to guide general management decisions. 


\subsection{1a Delineation}

Active hydrothermal areas as defined by:

- Active thermal features (hot springs, geysers, mudpots, steam vents).

- Thermal water greater than $30^{\circ} \mathrm{C}\left(86^{\circ} \mathrm{F}\right)$.

- Hydrothermal gases $\left(\mathrm{H}_{2} \mathrm{~S}, \mathrm{CO}_{2}\right)$ above Occupational Safety and Health Administration (OSHA) limits measured either above or below ground.

- High ground-surface temperatures as evidenced by the absence of deep-rooted vegetation or presence of recent sinter deposits.

- High subsurface ground temperatures as defined by a temperature at $75-\mathrm{cm}$ depth $10^{\circ} \mathrm{C}$ $\left(18^{\circ} \mathrm{F}\right)$ greater than a reference temperature at the same depth at a background site.

\subsection{1b Management Guidelines}

- Where hydrothermal activity is clearly evident, further development (addition or expansion) of infrastructure would be prohibited.

- Existing infrastructure should be retired or reduced as practical. Removal of wellfunctioning existing infrastructure is not indicated unless it can be demonstrated that negative interactions with the hydrothermal system are continuing or increasing. However, as opportunities for relocation/removal present themselves, they should be pursued. For example, rather than replacing old or degraded infrastructure in the red zone, it could be migrated to less sensitive areas.

- Protocols for maintenance of existing infrastructure (for example, underground utilities, parking lots, foundations) should be developed to minimize potential impacts to hydrothermal fluid and heat flows.

- Protocols should be developed to consolidate utility corridors and provide for limited above-ground utilities in areas determined to fall within red zones.

- Abandoned infrastructure should be carefully evaluated to determine whether its presence is affecting the hydrothermal system. If the abandoned infrastructure is determined to impact the hydrothermal system, removal or other methods should be implemented to reduce or eliminate its impact.

- Preventive removal of infrastructure abandoned in place is not indicated unless there is an identified negative impact on hydrothermal features, fluids, or heat flow.

\subsubsection{Green Zone}

Areas that show little evidence for active or recent near-surface hydrothermal activity are mapped as the green zone. Soils are dominated by glacial sands, often containing black obsidian fragments. Evidence for past hydrothermal activity (silica sinter, travertine, varicolored clays) is absent. High surface heat flow has not been identified. These areas have a low potential for hydrothermal activity negatively impacting infrastructure, infrastructure negatively impacting hydrothermal activity, or both. 


\subsection{2a Delineation}

An initial green zone can be defined as that area within the Upper Geyser Basin mapped as "glacial" by Muffler and others (1971) and located southwest of the Grand Loop Road (fig. 5). Subsurface ground temperatures at $75-\mathrm{cm}$ depth should be within $5^{\circ} \mathrm{C}\left(9^{\circ} \mathrm{F}\right)$ of temperatures at a reference background site.

\subsection{2b Management Guidelines}

- No hydrothermal-based constraints on development and maintenance of infrastructure. However, the following conditions should be reported to the park geology staff and prompt additional consideration:

- Groundwater warmer than $40^{\circ} \mathrm{C}\left(104^{\circ} \mathrm{F}\right)$.

- Geothermal gases (for example, smell of $\mathrm{H}_{2} \mathrm{~S}$ ).

- Hot spring deposits or clay deposits.

- If any of these conditions are encountered, a rapid reassessment of hydrothermal activity should occur. If the conditions for a red zone are documented, then construction should be reconsidered.

Development in these areas should be planned with allowance for these reporting requirements, including appropriate consideration of construction contingencies resulting from unanticipated encounters with hydrothermal conditions.

\subsubsection{Yellow Zone}

Yellow areas have unknown potential for hydrothermal activity that could negatively impact infrastructure and/or infrastructure impacts on hydrothermal activity. As site-specific studies and general research provide additional information, the yellow zone is expected to shrink in size relative to the well-characterized adjacent "red" and "green" zones. The "yellow" zones are an obvious priority for the local investigation techniques outlined in Section 2.0, "Knowledge Gaps and Suggested Topics for Future Study."

The eastern rim of Pocket Basin in the Lower Geyser Basin provides an example of a locality that previously had appeared to be completely free of hydrothermal activity because of the many lodgepole pine trees growing there. However, these trees were growing in a region underlain by old, decaying sinter. Very active mud pots subsequently appeared and grew over time (R.O. Fournier, written communication, December 2013). If development in this area had been contemplated, the old sinter would have been a useful clue of potential hydrothermal activity.

\subsection{3a Delineation}

- Generally located between the "red" and "green" zones.

- Inactive hydrothermal features without nearby active features.

- Proximal to red zone.

- An area of unknown potential for hydrothermal activity. 


\subsection{3b Management Guidelines}

- Avoid increasing the area of impermeable ground cover such asphalt, concrete, and buildings.

- Seek alternative locations for additional and existing infrastructure.

- Seek additional information on the occurrence and movement of hydrothermal fluids.

- Precede new development or infrastructure expansion with site-specific studies of thermal water, gases, temperatures, and heat flow. Investigations would include:

1. TIR imagery,

2. Temperature measurements at $0.75-1 \mathrm{~m}(30-39$ in) depth, with less than 5-m (16 ft) spacing,

3. Contemporaneous measurement of hydrothermal gases, and

4. A review of the site history with respect to construction, maintenance, or management issues related to hydrothermal activity.

Development could proceed after demonstrating absence of hydrothermal activity as described in the definition of red zones.

\section{Final Thoughts}

It is useful to consider a hypothetical situation where explorers have just discovered Old Faithful in 2014. How would it be developed? Where would the hotels, gas stations, and restaurants be located? How much parking space would be desired? Of course, those questions are moot. Highly valued buildings are now intimately associated with the conception of the geyser itself. Thousands of visitors drive into the area each day expecting to witness an eruption of Old Faithful and gaze upward at the balconies and rafters of the Old Faithful Inn. In trying to balance strategies for accommodating infrastructure, hydrothermal resources, and current scientific knowledge, we have sought to provide both present-day and long-term perspectives. Our goal is to ensure that the visitor experience at Old Faithful is just as good 100 years from now as it is today.

\section{Acknowledgments}

Authors of this report comprise the Old Faithful Science Panel, who met on June 3-5, 2013, at Old Faithful, Yellowstone National Park. The work of the panel benefited from a series of presentations by National Park Service personnel and park-associated researchers (listed in appendix 2), whom we thank for their important contributions. Joe Gardner of the USGS Utah Water Science Center re-drafted Figures 1, 2 and 5. Helpful reviews were provided by L.J.P. Muffler, USGS; Richard Allis, Utah Geological Survey; Clay Nichols retired, Idaho National Laboratory; and David Hallac, YNP. The Old Faithful Science Review Panel meeting was made possible through a grant from the Yellowstone Park Foundation. 


\section{References Cited}

Bauer, C.M., and Marler, G., 1939, Old Faithful, an example of geyser development in Yellowstone Park: Northwest Science, v. 13, p. 50-55.

Christiansen, R.L., 2001, The Quaternary and Pliocene Yellowstone Plateau volcanic field of Wyoming, Idaho, and Montana: U.S. Geological Survey Professional Paper 729-G, 144 p., http://pubs.usgs.gov/pp/pp729g/.

Christiansen, R.L., and Blank, H.R., Jr., 1974, Geologic map of the Old Faithful quadrangle, Yellowstone National Park, Wyoming: U.S. Geological Survey Geologic Quadrangle 1189, scale 1:62,500, http://pubs.er.usgs.gov/publication/gq1189.

Christiansen, R.L., Lowenstern, J.B., Smith, R.B., Heasler, H., Morgan, L.A., Nathenson, M., Mastin, L.G., Muffler, L.J.P., and Robinson, J.E., 2007, Preliminary assessment of volcanic and hydrothermal hazards in Yellowstone National Park and vicinity: U.S. Geological Survey Open-File Report 20071071, 98 p., http://pubs.usgs.gov/of/2007/1071/.

Department of the Interior and related agencies Appropriation Act, 1985, Pub. L. No 98-473, Sec. 319 , 98 Stat. 1837, 1874 (1985).

Dickie, B.N., and Luketina, K.M., 2005, Sustainable management of geothermal resources in the Waikato Region, New Zealand: World Geothermal Congress, 3d, Antalya, Turkey, 2005, 9 p.

Evans, W.C., Bergfeld, D., McGeehin, J.P., King, J.C., and Heasler, H., 2010, Tree-ring ${ }^{14}$ C links seismic swarm to $\mathrm{CO}_{2}$ spike at Yellowstone, USA: Geology, v. 38, p. 1,075-1,078.

Fenner, C.N., 1936, Bore-hole investigations in Yellowstone Park: Journal of Geology, v. 44, no. 2, p. 225-315.

Friedman, I., and Norton, D.R., 2007, Is Yellowstone losing its steam? Chloride flux out of Yellowstone National Park, in Morgan, L.A., ed., Integrated geoscience studies in the greater Yellowstone areaVolcanic, hydrothermal and tectonic processes in the Yellowstone geoecosystem: U.S. Geological Survey Professional Paper 1717, p. 274-297, http://pubs.usgs.gov/pp/1717/.

Fournier, R.O., 1989, Geochemistry and dynamics of the Yellowstone National Park hydrothermal system: Annual Review of Earth and Planetary Sciences, v. 17, p. 13-53, doi:10.1146/annurev.ea.17.050189.000305.

Fournier, R.O., Thompson, J.M., Cunningham, C.G., and Hutchinson, R.A., 1991, Conditions leading to a recent small hydrothermal explosion at Yellowstone National Park: Geological Society of America Bulletin, v. 103, p. 1,114-1,120.

Fournier, R.O., White, D., and Truesdell, A.H., 1976, Convective heat flow in Yellowstone National Park: United Nations Symposium on the Development and Uses of Geothermal Resources, 2d, San Francisco, Calif., 1975, v. 1, p. 731-739.

Gardner, W.P., Susong, D.D., Solomon, K., and Heasler, H.P., 2011, A multitracer approach for characterizing interactions between shallow groundwater and the hydrothermal system in the Norris Geyser Basin, Yellowstone National Park: Geochemistry, Geophysics, Geosystems, v. 12, no. 8, 17 p., doi:10.1029/2010GC003353.

Heasler, H., and Jaworowski, C., 2011a, Analyses of ground temperatures and geothermal gases in the Laurel dormitory area at Old Faithful, Yellowstone National Park, February 27, 2011: Yellowstone National Park Geology Program Internal Report, 19 p.

Heasler, H., and Jaworowski, C., 2011b, Anthropogenic impacts to the hydrothermal system within the Old Faithful area, Yellowstone National Park, October 18, 2011: Yellowstone National Park Geology Program Internal Report, 14 p. 
Heasler, H., Jaworowski, C., Feeney, C., and Foley, D., 2009a, Temperature measurements at the historic Old Faithful Inn, Yellowstone National Park, July 27, 2009: Yellowstone National Park Geology Program Internal Report, 8 p.

Heasler, H., Jaworowski, C., Feeney, C., Carr, B., and Foley, D., 2009b, Preliminary geothermal analyses of the area at the historic Old Faithful Inn, Yellowstone National Park, August 24, 2009: Yellowstone National Park Geology Program Internal Report, 19 p.

Heasler, H., Jaworowski, C., and Susong, D., 2004, A hydrothermal monitoring plan for Yellowstone National Park: internal report available through Yellowstone National Park archives, 24 p.

Hurwitz, S., Hunt, A.G., and Evans, W.C., 2012, Temporal variations of geyser water chemistry in the Upper Geyser Basin, Yellowstone National Park, USA: Geochemistry, Geophysics, Geosystems, v. 13, no. 12, Q12005, doi:1029/2012GC004388.

Hurwitz, S., Kumar, A., Taylor, R., and Heasler, H., 2008, Climate-induced variations of geyser periodicity in Yellowstone National Park, USA: Geology, v. 36, p. 451-454, doi: 10.1130/G24723A.1.

Hurwitz, S., Lowenstern, J.B., and Heasler, H., 2007, Spatial and temporal geochemical trends in the hydrothermal system of Yellowstone National Park-Inferences from river solute fluxes: Journal of Volcanology and Geothermal Research, v. 162, p. 149-171.

Husen, S., Taylor, R., Smith, R.B., and Heasler, H., 2004, Changes in geyser eruption behavior and remotely triggered seismicity in Yellowstone National Park produced by the 2002 M7.9 Denali fault earthquake, Alaska: Geology, v. 32, p. 537-540.

Hutchinson, R.A., Westphal, J.A., and Kieffer, S.W., 1997, In situ observations of Old Faithful geyser: Geology, v. 25, p. 875-878.

Ingebritsen, S.E., Galloway, D.L., Colvard, E.M., Sorey, M.L., and Mariner, R.H., 2001, Time-variation of hydrothermal discharge at selected sites in the western United States - Implications for monitoring: Journal of Volcanology and Geothermal Research, v. 111, p. 1-23.

Kieffer, S.W., 1984, Seismicity at Old Faithful geyser-An isolated source of geothermal noise and possible analogue of volcanic seismicity: Journal of Volcanology and Geothermal Research, v. 22, p. 59-95.

Livo, K.E., Kruse, F.A., Clark, R.N., Kokaly, R.F., and Shanks, W.C., III, 2007, Hydrothermally altered rock and hot-spring deposits at Yellowstone National Park, in Morgan, L.A., ed., Integrated geoscience studies in the greater Yellowstone area-Volcanic, hydrothermal and tectonic processes in the Yellowstone geoecosystem: U.S. Geological Survey Professional Paper 1717, p. 491-507, http://pubs.usgs.gov/pp/1717/.

Marler, G.D., 1964, Effects of the Hebgen Lake earthquake of August 17, 1959, on the hot springs of the Firehole Geyser basins, Yellowstone National Park, in The Hebgen Lake, Montana Earthquake of August 17, 1959: U.S. Geological Survey Professional Paper 435, p. 185-197, http://pubs.er.usgs.gov/publication/pp435.

Marler, G.D., and White, D.E., 1975, Seismic geyser and its bearing on the origin and evolution of geysers and hot springs of Yellowstone National Park: Geological Society of America Bulletin, v. 86, p. 749-759.

McCleskey, R.B., Clor, L.E., Lowenstern, J.B., Evans, W.C., and Nordstrom, D.K., 2012, Solute and geothermal flux monitoring using electrical conductivity in the Madison, Firehole and Gibbon Rivers, Yellowstone National Park: Applied Geochemistry, v. 27, p. 2,370-2,381.

Morgan, L.A., Shanks, W.C.P., III, and Pierce, K.L., 2009, Hydrothermal processes above the Yellowstone magma chamber-Large hydrothermal systems and large hydrothermal explosions: Geological Society of America Special Paper 459, 95 p. 
Muffler, L.J.P., White, D.E., Beeson, M.H., and Truesdell, A.H., 1982, Geologic map of Upper Geyser Basin, Yellowstone National Park, Wyoming: U.S. Geological Survey Miscellaneous Investigations Series Map I-1371, scale 1:4,800.

Muffler, L.J.P., White, D.E., and Truesdell, A.H., 1971, Hydrothermal explosion craters in Yellowstone National Park: Geological Society of America Bulletin, v. 82, p. 723-740.

National Park Service, 2006, Management Policies 2006: 180 p., accessed February 21, 2014, at http://www.nps.gov/policy/MP2006.pdf.

National Park System Advisory Board Science Committee, 2012, Revisiting Leopold - Resource stewardship in the National parks: National Park Foundation, 24 p., http://www.nps.gov/calltoaction/PDF/LeopoldReport_2012.pdf.

Pearson, F.J., Jr., and Truesdell, A.H., 1978, Tritium in the waters of Yellowstone National Park, in Zartman, R.E., ed., Short papers of the fourth International Conference, Geochronology, Cosmochronology, Isotope Geology, 1978: U.S. Geological Survey Open-File Report 78-701, p. $327-$ 329., http://pubs.er.usgs.gov/publication/ofr78701.

Rowe, J.J., Fournier, R.O., and Morey, G.W., 1965, Use of sodium iodide to trace underwater circulation in the hot springs and geysers of the Daisy Group, Yellowstone National Park, in Geological survey research 1965: U.S. Geological Survey Professional Paper 525-B, p. B184-186., http://pubs.er.usgs.gov/publication/pp525B.

Rye, R.O., and Truesdell, A.H., 2007, The question of recharge to the deep thermal reservoir underlying the geysers and hot springs of Yellowstone National Park, in Morgan, L.A., ed., Integrated geoscience studies in the Greater Yellowstone Area-Volcanic, hydrothermal and tectonic processes in the Yellowstone geoecosystem: U.S. Geological Survey Professional Paper 1717, p. 239-270, http://pubs.usgs.gov/pp/1717/.

Vandemeulebrouck, J., Roux, P., and Cros, E., 2013, The plumbing of Old Faithful geyser revealed by hydrothermal tremor: Geophysical Research Letters, v. 40, p. 1,989-1,993.

White, D.E., 1991, Whistle, a nearly dormant geyser in Upper Geyser Basin, Yellowstone National Park, Wyoming - The first geyser to be studied by research drilling: U.S. Geological Survey Bulletin 1967, 13 p., http://pubs.er.usgs.gov/publication/b1967.

White, D.E., Fournier, R.O., Muffler, L.J.P., and Truesdell, A.H., 1975, Physical results of research drilling in thermal areas of Yellowstone National Park, Wyoming: U.S. Geological Survey Professional Paper 892, 70 p., http://pubs.er.usgs.gov/publication/pp892. 


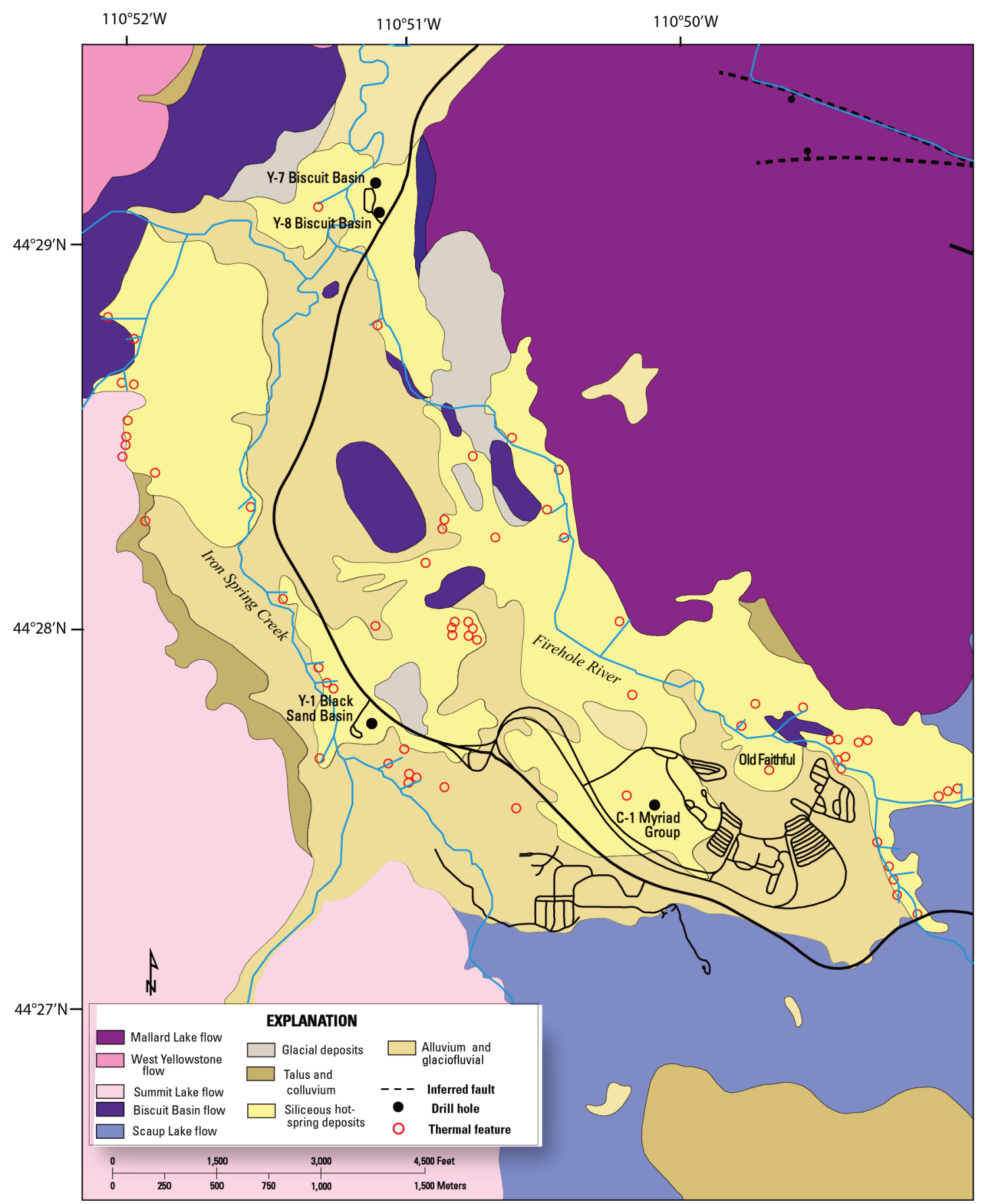

Figure 1. Geologic map of Old Faithful area. The Mallard Lake, Summit Lake, and Scaup Lake lava flows surround the Upper Geyser Basin. Glacial and post-glacial sediments (tan and yellow) were deposited in between and on top of the lava flows. Older lavas (purple) are mostly buried by the younger sediments. The thick black line is the main road, and black lines are other roads in the Old Faithful area. Wells completed for scientific drilling prior to 1970 are labeled black circles located at Biscuit and Black Sand Basins and near the Myriad Group. Original bedrock mapping by Christiansen and Blank (1974). 


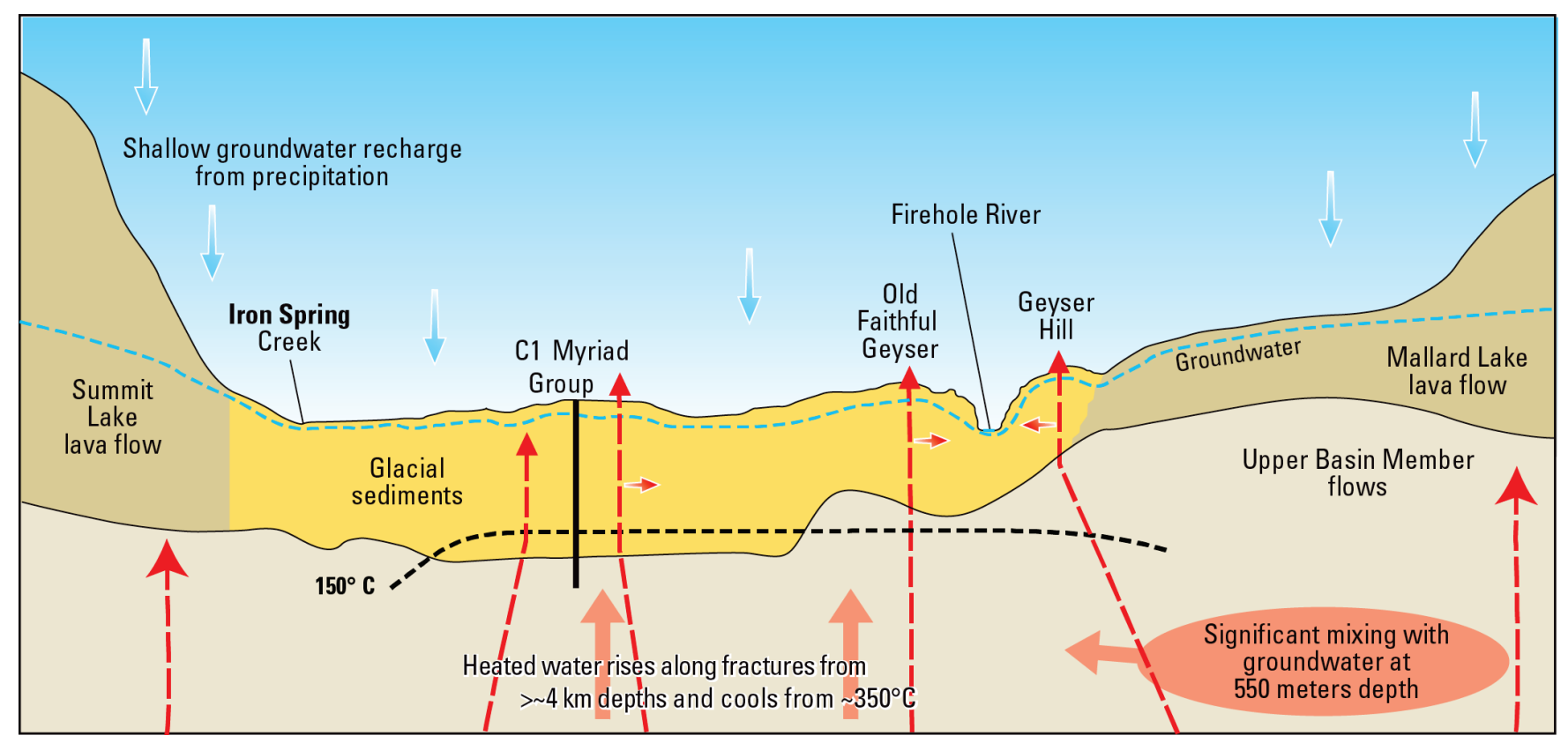

Figure 2. Schematic cross section along a 5-kilometer $(3.1 \mathrm{mi})$ profile from southwest to northeast through the Upper Geyser Basin. Vertical exaggeration is about 4X. Glacial sediments that fill the valley overlie volcanic rocks of various ages, all greater than 100,000 years old. The C-1 drillhole extended 130 meters (400 feet) through the glacial sediments and into the underlying lava. The dashed blue line represents the water table. Blue arrows above land surface represent precipitation that becomes groundwater recharge. The black dashed line is the approximate depth at which waters reach $150^{\circ} \mathrm{Celsius}\left(302^{\circ} \mathrm{F}\right)$. Red-dashed lines represent hypothetical fractures through which hot waters rise from depth. Fluid pressures in these hot-water filled fractures are sufficiently high to limit ingress of cold waters. Small horizontal red arrows represent hot water flow into shallow aquifers. 

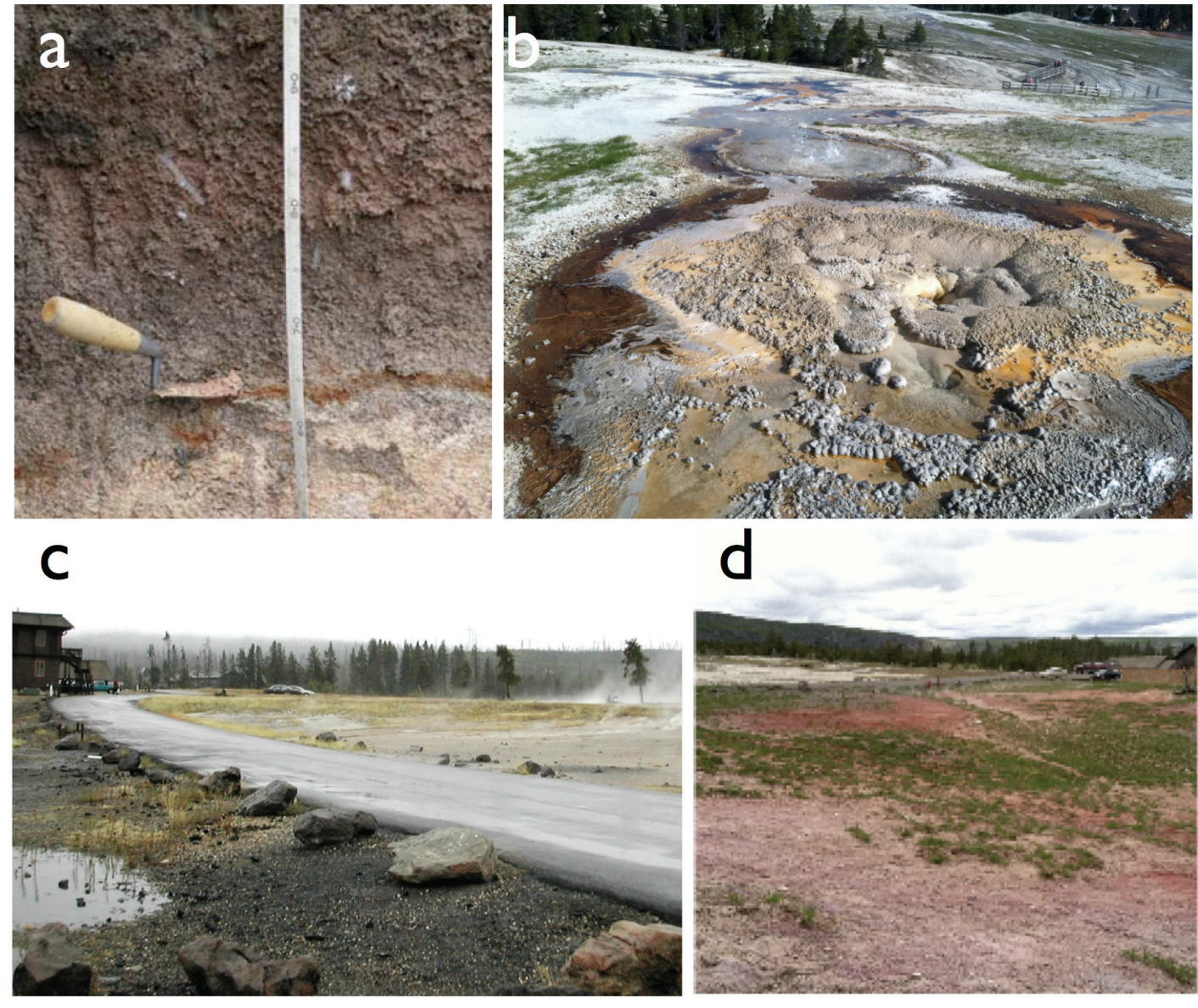

Figure 3. Photographs of various types of sediments and hydrothermal deposits in the Old Faithful area. a, obsidian-rich sands form the basis for soils. b, a sinter apron around the orifice of Anemone Geyser. c, to right (west) of road, is a steam-heated area in the Myriad Group with clay alteration. $d$, red low-permeability clay associated with earlier alteration and oxidation. 


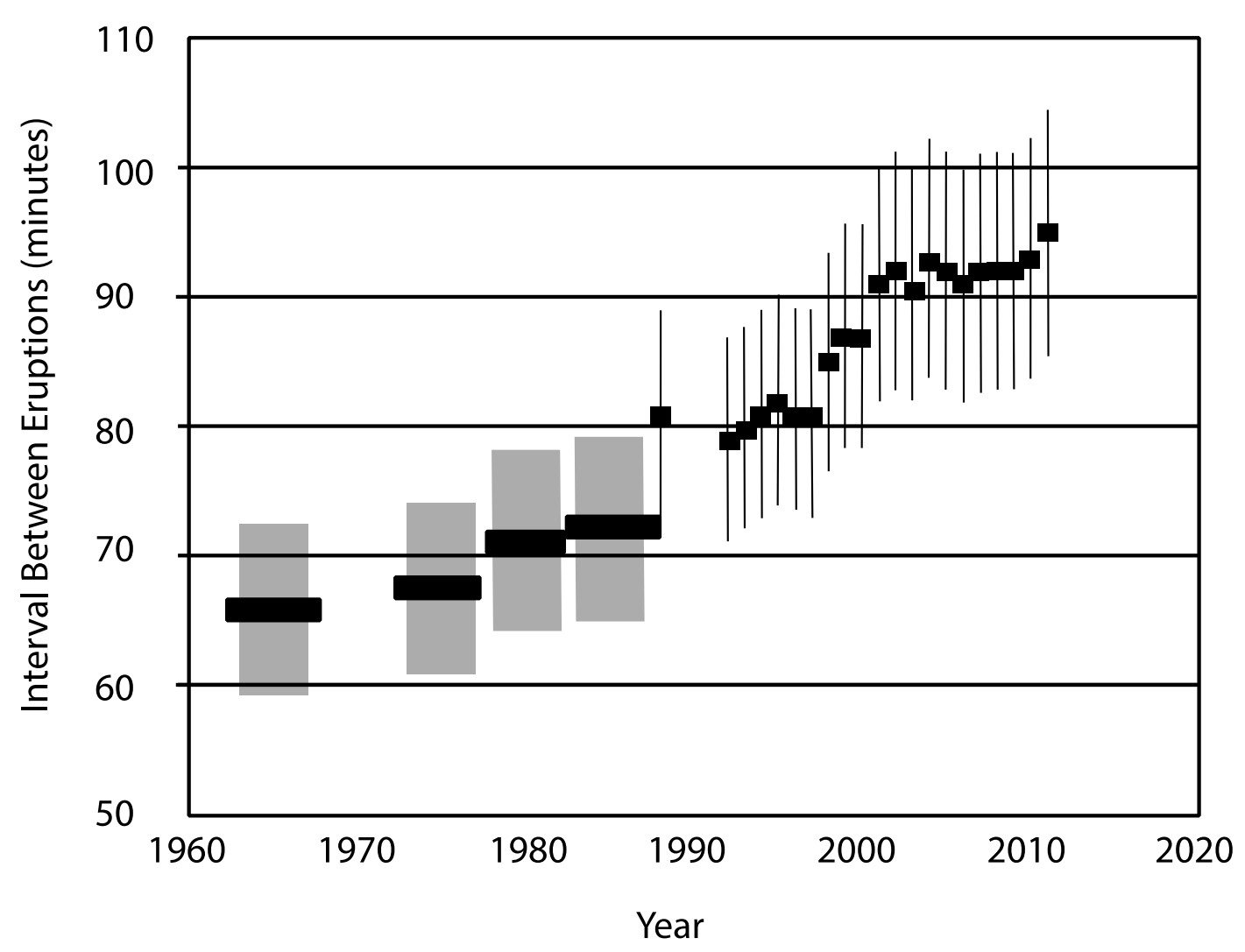

Figure 4. Boxplot showing increase in the eruption interval of Old Faithful from 1960 to the present. Post-1990 data points (black squares) are annual median values with their associated standard error. Pre-1990 data (black bands) represent averages of multiple years with a 10-percent error (gray boxes). Data compiled by Lynn Stephens from National Park Service log books. 


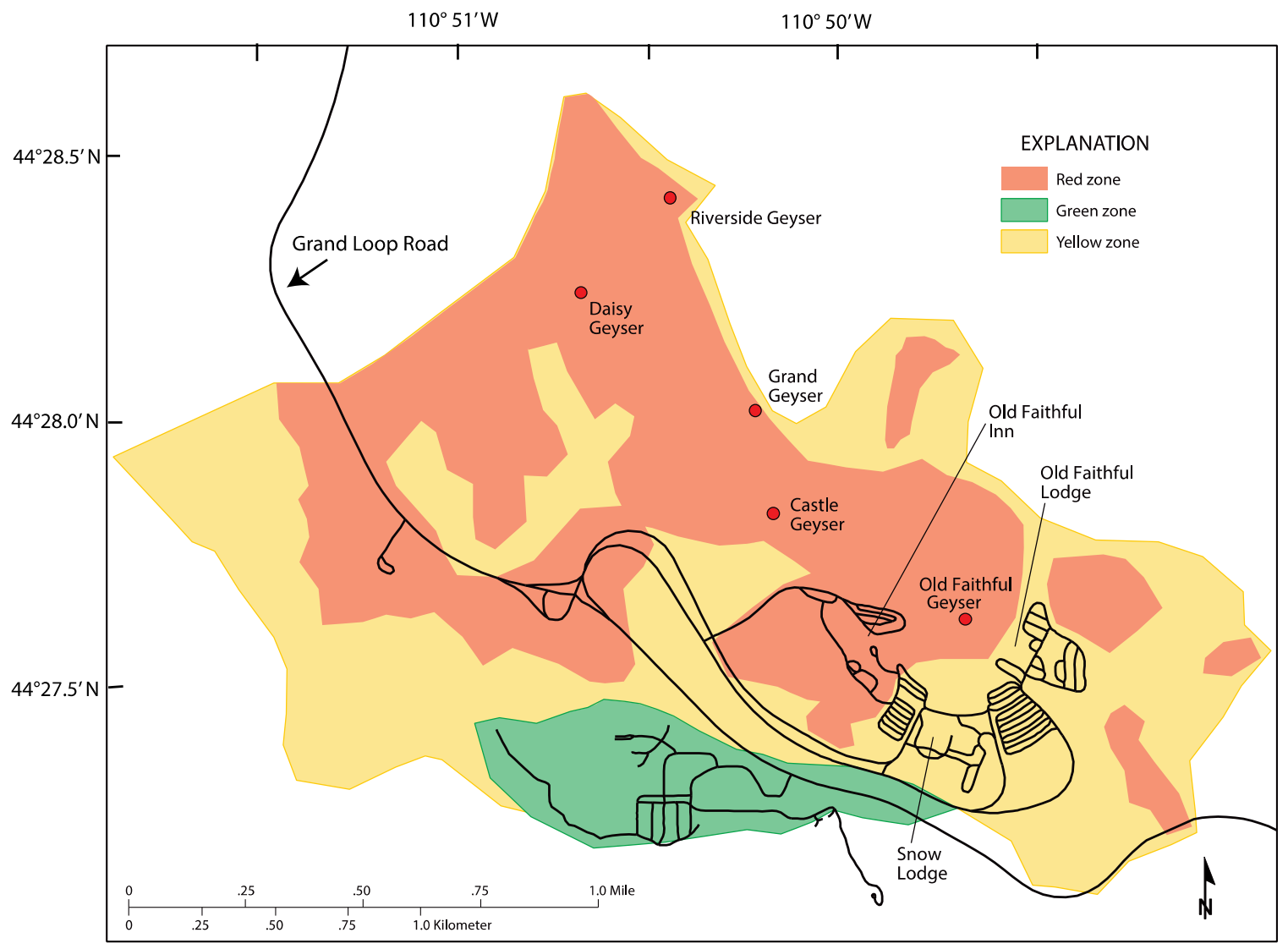

Figure 5. Map of the Old Faithful area delineating zones for the protection of the hydrothermal resource and infrastructure. The red zones are areas with high potential for hydrothermal activity negatively impacting infrastructure and/or infrastructure negatively impacting natural hydrothermal activity; the green zones have minimal hydrothermal-based constraints on development/maintenance of infrastructure; and the yellow zones are areas with unknown potential for hydrothermal activity in which site-specific studies should precede development (see Section 3.3, "An Approach to Infrastructure Maintenance and Development," for additional discussion). 
Table 1. Proposed Zone System for Old Faithful Area.

\begin{tabular}{|c|c|c|c|}
\hline & Red Zone & Yellow Zone & Green Zone \\
\hline Definition & Hydrothermal activity present & Potential hydrothermal activity & $\begin{array}{l}\text { No current evidence of hydrothermal } \\
\text { activity }\end{array}$ \\
\hline Criteria & $\begin{array}{l}\text { Active hot springs, geysers, } \\
\text { vents or mud pots } \\
\text { High hydrothermal gas } \\
\text { concentrations } \\
\text { High ground temperatures } \\
\text { High heat flow }\end{array}$ & $\begin{array}{l}\text { Potential subsurface hydrothermal } \\
\text { activity } \\
\text { Potential high hydrothermal gas } \\
\text { concentrations } \\
\text { Potential high ground temperatures } \\
\text { Potential high heat flow }\end{array}$ & $\begin{array}{l}\text { Hydrothermal deposits absent } \\
\text { Low hydrothermal gas concentrations } \\
\text { Low ground temperatures } \\
\text { Low heat flow }\end{array}$ \\
\hline $\begin{array}{l}\text { Management } \\
\text { Guidelines }\end{array}$ & $\begin{array}{l}\text { New or expanded } \\
\text { infrastructure prohibited } \\
\text { Where practical remove } \\
\text { infrastructure } \\
\text { Special protocols for } \\
\text { infrastructure } \\
\text { maintenance }\end{array}$ & $\begin{array}{l}\text { Seek alternative locations in Green } \\
\text { Zone } \\
\text { Site specific investigations of } \\
\text { hydrothermal activity: } \\
\text { hydrothermal gases } \\
\text { ground temperatures } \\
\text { heat flow } \\
\text { Consider special design and } \\
\text { maintenance protocols } \\
\text { Development can proceed if Green } \\
\text { Zone Criteria met at specific site }\end{array}$ & $\begin{array}{l}\text { No hydrothermal constraints on } \\
\text { infrastructure development. (Planning } \\
\text { should allow for accommodation of } \\
\text { unanticipated conditions encountered } \\
\text { during construction.) }\end{array}$ \\
\hline
\end{tabular}




\section{Appendix 1. Legal Mandates, Authorities, and Policies Governing the Protection of Geothermal Resources in Yellowstone National Park}

Specific legal mandates, authorities, and policies address geothermal protection in Yellowstone National Park (YNP). YNP was created by an Act of Congress in 1872. The law mandated that Congress "...shall provide for the preservation, from injury or spoliation, of all timber, mineral deposits, natural curiosities, or wonders within said park, and their retention in their natural condition [17 Stat. 32]." The National Park Service Organic Act of 1916 states that units of the National Park system shall be managed "to conserve the scenery and the natural and historic objects and wildlife therein and to provide for the enjoyment of the same in such manner and by such means as will leave them unimpaired for the enjoyment of future generations." (16 USC 1)

National Park Service (NPS) policies direct the protection of geothermal resources within a park. The NPS Management Policies 2006 manual states that "The National Park Service will preserve the natural resources, processes, systems, and values of units in the national park system in an unimpaired condition, to perpetuate their inherent integrity and to provide present and future generations with the opportunity to enjoy them" (National Park Service, 2006, chap. 4). The manual contains specific guidelines for the protection of geothermal resources within a National Park. "Superintendents will strive to maintain the natural integrity of thermal systems, including the movement of air and/or water through heated rock, cold water recharge, the proximity of hot and warm water to the heat source, and the hydrostatic pressure and elevated temperature. Superintendents will work to prevent unacceptable impacts on thermal resources caused by development" (National Park Service, 2006, chap. 4, section 4.8.2.3).

The most recent guiding principle for the protection of geothermal resources within YNP is stated in a 2012 report titled "Revisiting Leopold: Resource Stewardship in the National Parks-A Report of the National Park System Advisory Board Science Committee": "NPS managers and decision makers will need to embrace more fully the precautionary principle as an operating guide... The precautionary principle requires that stewardship decisions reflect science-informed prudence and restraint. This principle should be integrated into NPS decision making at all levels." (p. 15.)

A primary focus of past legislation has been the protection of YNP's geothermal resources from threats outside of the park. A discussion of this legislation is valuable to illustrate the importance of protecting YNP's geothermal resources

The Geothermal Steam Act of 1970, as amended in 1988 (102 Stat. 1766), seeks to preserve geothermal features in units of the National Park System. Specific lists of parks with geothermal features are provided. YNP is discussed separately: "the entire park unit is listed as a significant thermal feature..." (Federal Register, v. 52, p. 28795). Specifically, the law directs the Department of Interior to monitor significant thermal features (30 USC $§ 1026$ Mineral Lands and Mining). 
In 1994, the State of Montana and the NPS entered into a Water Rights Compact describing the reserved federal water rights for five NPS units within the State (85-20-401 M.C.A.). As part of this Compact, Article IV established the Yellowstone Controlled Groundwater Area (YCGA) in an area of Montana outside of the park's boundary where special regulations apply. The stated purpose for establishing the YCGA is to "allow no impact to the hydrothermal system within the reserved lands of YNP.” Montana State agencies are required to monitor geothermal features outside the park's boundaries within the YCGA for potential impact to the YNP system. Geothermal monitoring within the park provides critical information to assess impacts from future development proposals.

The State of Wyoming has created a $24 \mathrm{~km}$ (15mi) buffer zone around YNP governing for permits to appropriate commercial groundwater use. The application to the Wyoming State Engineer Office to appropriate groundwater will contain "information necessary to show that the proposed development will not impair or produce an injurious effect on the hydrothermal system or hydrothermal features located within the boundaries of Yellowstone National Park." (W.S. 41-3-930).

A Water Rights Agreement between the State of Idaho and the United States for YNP was signed in 1992 as Water Rights Agreement between the State of Idaho and the United States for Yellowstone National Park, January 16 - May 14, 1992, State of Idaho and the United States In this agreement, the NPS received federal reserved water rights for groundwater "as is necessary to maintain the natural thermal features such as geysers, mudpots, hot springs, and similar features." This amount of groundwater is unquantified and will be resolved as the need arises.

Federal land in the Island Park Known Geothermal Resource Area (KGRA), located immediately west of YNP in Idaho, has been placed off-limits to geothermal leasing due to concerns about potential impacts to the YNP geothermal system. "Notwithstanding any other provision of law, the Secretary shall not issue any geothermal lease pursuant to the Geothermal Steam Act of 1970 (Public Law 91-581, as amended) in the Island Park Known as Geothermal Resource Area adjacent to Yellowstone National Park." (Department of the Interior and related agencies Appropriation Act, 1985). 


\section{Appendix 2. Presentations to the Old Faithful Science Review Panel, June 3-4, 2013}

Introductions - Daniel Wenk, Yellowstone National Park Superintendent

David Hallac, Chief, Yellowstone Center for Resources

History of the Old Faithful Area - Lee Whittlesey, YNP Park Historian

Cultural issues - Tobin Roop, Branch Chief of Cultural Resources, Yellowstone Center for Resources.

Infrastructure and maintenance challenges in the OF area-

Nancy Ward, Chief, YNP Maintenance

George Helfrich, Chief, YNP Concessions

Ann Rodman, Branch Chief, Yellowstone Center for Resources

Law Enforcement issues - Colleen Rawlings, District Ranger, Old Faithful

Interpretation issues- Linda Young, Chief, YNP Resource Education and Youth Programs

Lessons learned from geothermal development in New Zealand- Rick Allis, Utah State Geologist, Utah State Geological Survey

Geologic overview of the Old Faithful area- Jake Lowenstern, USGS Research Geologist Age dating and isotopic studies of hydrothermal water in YNP - Payton Gardner, Sandia National Laboratories

Thermal waters discharged by the hot springs and geysers of the Old Faithful Area- Bob Fournier, USGS, retired

Numerical modeling of hydrothermal systems- Steve Ingebritsen, USGS, Research Hydrologist

Airborne thermal infrared studies of the OF area: visualization of anthropogenic changes to the Old Faithful hydrothermal system - Cheryl Jaworowski, Geologist, YNP

Near surface observations of groundwater movement and heat transfer in the Old Faithful areaHenry Heasler, Park Geologist, YNP 